\title{
Antioxidant Activities, Total Phenolic Compound And Pigment Contents of Tropical Sargassum sp. Extract, Macerated In Different Solvents Polarity
}

\author{
Jelita Rahma Hidayati ${ }^{1}$, Ervia Yudiati ${ }^{1,2^{*}}$, Delianis Pringgenies ${ }^{1}$, Zaenal Arifin ${ }^{3}$ and \\ Diah Tri Oktaviyanti 1
}

\author{
'Department of Marine Science, Faculty of Fisheries and Marine Science, Diponegoro University \\ 2Laboratory of Tropical Marine Biotechnology \\ Jl. Prof. H. Soedharto, SH., Tembalang, Semarang, Indonesia 50275 \\ ${ }^{3}$ Balai Besar Perikanan Budidaya Air Payau Jepara \\ Jl. Cik Lanang, Rw. IV, Bulu, Jepara, Indonesia 59418 \\ Email: eyudiati@gmail.com
}

\begin{abstract}
Exposure of sunlight lead tropical Sargassum sp. to maintain their growth and moreover to bring up their secondary metabollite for life struggling. Sargassum sp. has bioactive compounds that has a potential antioxidant acitivity such as phenolic compounds as well as chlorophyll and carotenoids. This research was conducted to determine antioxidant activities, phenolic compound and pigmens of Sargassum sp. with different solvent that have different polarities. Sample was macerate with n-heksana, ethyl acetate, methanol and aquadest. All the parameters were done spectrophotometrically. IC 50 was used to determine the antioxidant activity by antiradical scavenging activity using DPPH $(515 \mathrm{~nm})$. Total phenolic compound were tested by Folin-Ciocalteu solution and used gallic acid as standard $(725 \mathrm{~nm})$. The chlorophylls a content were measured at wavelength $662 \mathrm{~nm}$ and $645 \mathrm{~nm}$ and carotenoids were measured at wavelength $470 \mathrm{~nm}$. The results showed best $I C_{50}$ is achieved by aquadest extract (72.95 $\left.\pm 0.22 \mathrm{ppm}\right)$. The highest Total phenolic compound is achieved by ethyl acetat extract (120.29 $\pm 0,404 \mathrm{mg}$ GAE/g sample). The highest chlorophyll a content is achieved by ethyl acetat extract $(18.23 \pm 0,049 \mathrm{mg} / \mathrm{g} \mathrm{sample})$ and the highest carotenoid content is achieved by ethyl acetat extract extract $(60.65 \pm 0,008 \mu \mathrm{mol} / \mathrm{g}$ sample). It can be concluded that aquadest extract can be categorized as the strong antioxidant and antiradical activity, ethyl acetat as a medium antioxidant activity. The simple and save methods of aquadest extract promising that Sargassum sp. frorn Indonesia is a good candidate compoud for nutraceutical and cosmeceutical approach.
\end{abstract}

Keywords : Sargassum sp.; Antioxidant; TPC; Pigment

\section{INTRODUCTION}

Brown seaweed is an abundant biological resource in Indonesia. Unfortunately, its not utilizated optimally. This plant lives in shallow waters to a certain depth until sunlight can penetrate it. This exposure causes the formation of free radicals or another reactive oxygen species, but this plant is able to adapt so that the structural components do not influence to the oxidative damage (Nursid, 2013). Brown seaweed has potential source of bioactive compounds such as alkaloids, glycosides, tannins and steroids used in the pharmaceutical industry (Sathya et al., 2017). The bioactive compounds are Phlorotannins, phenolic (Tanniou et al., 2014) and flavonoid compounds that can inhibit LDL oxidation, Angiotensin Converting Enzyme (ACE), aamylase and a-glucosidase (Nagappan et al., 2017). Moreover Sargassum sp. compound has antioxidant activity (Diachanty et al., 2017).

Antioxidants are compounds or substances that can inhibit, delay, prevent or slow down oxidation reactions. Oxidation is a 
chemical reaction that can produce free radicals such as superoxide anions $\left({ }^{*} \mathrm{O}_{2}\right)$, hydroxyl radicals $\left(\mathrm{OH}^{*}\right)$, alkoxyl radicals $\left(\mathrm{RO}^{*}\right)$, peroxyl radical (ROO*), (OONO*), hydrogen peroxide $\left(\mathrm{H}_{2} \mathrm{O}_{2}\right)$ and singlet oxygen $\left({ }_{1} \mathrm{O} 2\right)$, which triggers a chain reaction (Nimse and Pal, 2015). This free radical is one of the main cause of various degenerative diseases such as cancer (Padua et al., 2015).

Based on the source, antioxidants are classified as synthetic and natural antioxidants. Synthetic antioxidants are obtained from the synthesis of chemical reactions such as BHA (Butylated hydroxy anosol), BHT (butylated hydroxy tolvene), TBHQ (tertiary butyl hydro quinone), Propyl Galat and AAT (Analog alpha tocopherol). Synthetic antioxidants have a usage limit of $0.02 \%$ from a total fat. If those used excessively, it can be induced the carcinogenic effect (Fitri, 2013). it makes the source of natural antioxidant compounds important to explore and develop.

Sargassum sp. contains bioactive compounds such as flavonoids, triterpenoids, polyphenols (Nurjanah et al., 2016), chlorophyll, carotenoids and alkaloids (Ghazali et al., 2018) which can be used as a source of natural antioxidants. Hwang et al. (2010) reported S. hemyphyllum had an $I_{50}$ value of $1.58 \mathrm{mg} / \mathrm{ml}$. S. hytrix sample collected in the dry season has an inhibition percentage to reduce free radicals at $48.71 \%$ and has a total phenolic compound of 21.99 g PGE/100 g extract (Budhiyanti et al., 2012). Sargassum sp. has an inhibition percentage to reduce free radicals at $81.35 \%$ (Sedjati et al., 2017) and has a total phenolic compound of $127.4 \mathrm{mg} / \mathrm{g}$ (Cho et al., 2007).

This study aims to determine the antioxidant activity of n-hexane, ethyl acetate, methanol and aquadest extract of tropical Sargassum sp. and determine the content of phenolic compounds, chlorophyll a and carotenoids.

\section{MATERIALS AND METHODS}

The Sargassum sp. sample was collected from Teluk Awur Waters, Jepara and Krakal Waters, Yogyakarta. Soon as came in to the laboratory, the samples were washed using fresh water and dried up at room temperature. Extraction of the Sargassum sp. was done by gradual maceration using solvents with different polarity ie. n-hexane (non-polar), ethyl acetate (semi-polar) and methanol (polar) (Hidayati et al., 2017). Extraction of Sargassum sp. with aquadest performed with different sample and macerated with some modification.

A 250 gram dry sample was cut into small pieces ( $\pm 5 \mathrm{~mm}$ ) and macerated using $1000 \mathrm{~mL} \mathrm{n}$-hexane solvent for 24 hours at \pm $27^{\circ} \mathrm{C}$, then filtered. The residue is remacerated for 24 hours and refiltered. The n-hexane filtrate was concentrated using a rotary evaporator at $35^{\circ} \mathrm{C}$. The seaweed residue was re-extracted with ethyl acetate and methanol solvent in a similar manner.

Basically, extraction of Sargassum sp. by aquadest was administered on method by Sedjati et al. (2017) with slight modification. The sample was extracted using aquadest with a ratio of $1: 20(\mathrm{w} / \mathrm{v})$ in a hot plate magnetic stirrer for 30 minutes. The supertantant was filtered using Whatman filter paper No.41. The extract was then concentrated and cool dried. The extract was then stored in the refrigeration for the next test.

\section{Determination of DPPH Maximum Absorbance}

A $4 \mathrm{mg}$ DPPH (2,2-diphenyl-1picrylhydrazyl) was weighed and dissolved in $100 \mathrm{ml}$ of methanol to produce a DPPH $(2,2-$ diphenyl-1-picrylhydrazyl) solution with a concentration of $0.1 \mathrm{mM}$. This solution was taken $4 \mathrm{~mL}$ then put into the cuvette and observed the absorbance using a spectrophotometer (Shimadzu UV-1280) at a wavelength of $400-800 \mathrm{~nm}$ (Mardiyah et al., 2014). The highest absorbance at certain wavelength will then be used to measure antioxidant activity.

\section{The Assessment of Antioxidant Activity}

Antioxidant activity determination was carried out using spectrophotometric methods (Moubayed et al., 2017). A total of 3 
$\mathrm{mL}$ of the test solution was added with $1 \mathrm{~mL}$ of DPPH $0.1 \mathrm{mM}$. The solution was incubated for 30 minutes and then measured the absorbance at the maximum wavelength. The percentage of inhibition is calculated using the formula (Banerjee et al., 2005). The inhibition percentage data was plotted to constructed the linear regression equation and determined the $\mathrm{IC}_{50}$ value.

\section{Measurement of Total Phenolic Compound}

Determination of total phenolic compound of Sargassum sp. was performed using Folin-Ciocalteu and gallic acid reagents as standard (Agustini, 2015). A $5 \mathrm{mg}$ gallic acid is dissolved in $5 \mathrm{~mL}$ ethanol to obtain a 1000 ppm stock solution. The stock solutions were diluted using methanol p.a. to obtain some series of concentrations $(5,10,15,20$ and $25 \mathrm{ppm}$ ). A $200 \mu \mathrm{L}$ of each concentration was taken, then followed by the addition of $10 \mathrm{~mL}$ of aquadest and $1 \mathrm{~mL}$ of FolinCiocalteu reagent. The solution was left for 5 minutes then added $1 \mathrm{~mL}$ of $7.5 \% \mathrm{Na}_{2} \mathrm{CO}_{3}$ solution and incubated at room temperature for 2 hours in dark conditions (Norra et al., 2016). Absorbance was measured using a spectrophotometer (ShimadzU UV-1280) at a wavelength of $720 \mathrm{~nm}$ (lltera et al., 2018). The value of total phenolics is expressed in $\mathrm{mg}$ Galic Acid Equivalent (GAE)/1000 g) (Ghafar, 2010).

\section{Assessment of Chlorophyll a and Carotenoids Compounds}

Each extract was dissolved with acetone p.a at $100 \mathrm{ppm}$ and $3 \mathrm{~mL}$ taken in a cuvette. The solution was measured for absorbance at a wavelength of $645 \mathrm{~nm}, 662$ $\mathrm{nm}$ and $470 \mathrm{~nm}$ (Kurniawan, 2010). Most carotenoids absorb lights in the region between 400 and $500 \mathrm{~nm}$ and chlorophylls absorb light at 645 and $662 \mathrm{~nm}$ at room temperature (Fabrowska et al., 2017). The content of chlorophyll a and carotenoids is calculated based on the following formula by Gross (1991).

\section{Statistical Analysis}

All data were subjected to one-way analysis of variance (ANOVA) at the level of significance of 0.05. A multiple comparison
(LSD) test was used to examine significant differences among treatments using IBM SPSS Statistics 20 Computer Software. Before the analysis, the raw data were normalized using some transformation depend on the type of data.

\section{RESULT AND DISCUSSION}

In this study Sargassum sp. extracted step by step with $\mathrm{n}$-hexane (non polar), ethyl acetate (semi-polar) and methanol (polar) solvents. This is intended to get the maximum extraction. This because each solvent has the ability to dissolve compounds with the same polarity (Sarastani et al., 2002). The general principle in solvent extraction "like dissolve like" means that suitable solvent only dissolve suitable substance with similar polarities as the solvent used (Shipeng et al., 2015). The extraction process provides a varied yield and the highest yield obtained by aquadest extract (8.5\%). This is postulated due to the heating and stirring process using a magnetic stirrer which is carried out during extraction. According to Frary and Earle (1996) heating and stirring process will accelerate extraction, so, that, will increase the intensity of interaction the materials with solvents. Puspita et al. (2017) showed that S. ilicifolium extracted with water, produced more yield $(14.7 \pm 0.8 \%)$ than extracted with ethyl acetate $(7.3 \pm 1.0 \%)$. The solid-liquid extraction process is influenced by several factors, including extraction time, temperature used, stirring, and the number of solvents used (Harborne, 1996).

The maximum absorbance value of DPPH is reached at a wavelength of $515 \mathrm{~nm}$. Nicklisch and Waite (2014) also identified the maximum absorbance of DPPH compounds at a wavelength of $515 \mathrm{~nm}$, while Hidayati et al. (2017) obtain maximum DPPH absorbance at a wavelength of $514 \mathrm{~nm}$. The difference in DPPH maximum wavelength probably caused by type and specifity of the instruments used and time of observation (Molyneux, 2004).

Based on results of the antioxidant activity of Sargassum sp. extract, each solvent performed different IC 50 values (Figure 
1). Aquadest extract has strong antioxidant activity with $\mathrm{IC}_{50}$ value of $72.95 \pm 0.22 \mathrm{ppm}$. Ethyl acetate extract has moderate antioxidant activity with IC 50 value of 102.4 $\pm 0,056 \mathrm{ppm}$, while methanol and $\mathrm{n}$-hexane extracts have very weak antioxidant activity with IC 50 values less then 250 ppm.

The different solvents resulted different antioxidant activity. The compound will dissolve in solvents that have the same polarity (Harborne, 1987). This indicates that the extract contents of Sargassum sp. was dominated by polar compounds. However, there was a significant difference in $\mathrm{IC}_{50}$ values in two solvents ie. methanol and aquadest extract. In fact, those solvents is cathegorized as polar solvents. According to Senapati et al. (2016) aquadest has greater polarity than methanol solvents, so it can attract more polar compounds, especially polyphenols. Research by Yudiati et al. (2018a and 2018b) showed that alginate extract from tropial Sargassum sp. also has the ability to inhibit free radicals through their hydroxyl groups.

In this present research, The $\mathrm{IC}_{50}$ value was slightly higher (72.95 $\pm 0.22 \mathrm{ppm})$ than Sedjati et al. (2018) (69,274 ppm) and lower than Hidayati et al. (2017) (99.166 ppm). The different result occurs because the antioxidant activity are varied, depends on the species of seaweed (Parthiban et al., 2014), location (Mirghani et al., 2018) and seasons (Khairy and El-Sheikh, 2015), respectively. The low $\mathrm{IC}_{50}$ value indicates a

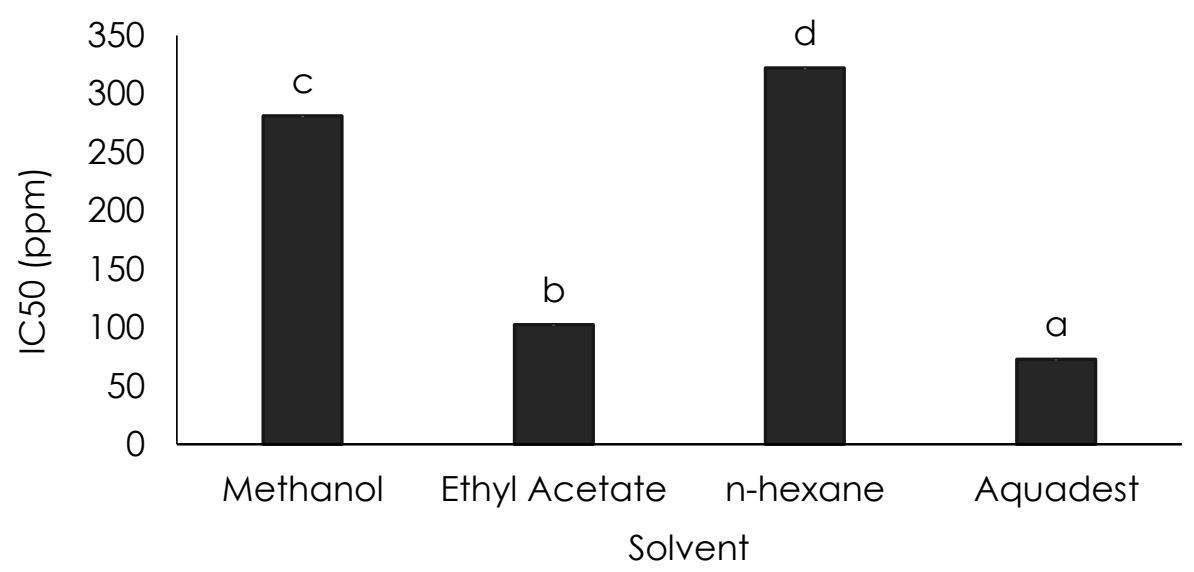

Figure 1. IC 50 value of Sargassum sp. Extract $(\mathrm{ppm})$ macerated in different solvents. Bars with

different letters indicate the significantly difference $(p<0.05)$ strong antioxidant activity. Those act as a hydrogen atom donor (Sarini et al. 2014). Antioxidant compounds can directly react with free radicals and turn them into new, less active and less dangerous free radicals (Sayuti and Yenrina, 2015).

Phenolic compounds have a direct correlation with antioxidant activity. Gazali et al. (2018) shows that $99 \%$ of antioxidant activity is the result of the phenol compounds contribution, whereas $1 \%$ is thought to be a contribution from other compounds that have antioxidant abilities. The ability to reduce free radicals is related to the hydroxyl groups present in phenol compounds (Mehdinezhad et al. 2016). The hydroxyl group function act as a contributor to hydrogen atoms. It will reacting with free radicals through the electron transfer mechanism.

Different extract had a different total phenolic compound (Figure 2.) The highest content was found in ethyl acetate extract with a value of $120.29 \pm 0.404 \mathrm{mg} \mathrm{GAE} / \mathrm{g}$ sample. This result is much higher than $S$. vulgare ethyl acetate extract which is $5.77 \pm 0.33 \mathrm{mg} \mathrm{GAE} / \mathrm{g}$ sample (Khaled et al., 2012). Sadati et al. (2015) also showed the lowest result total phenolic compound of $S$. swartzii ethyl acetate extract which is 0.81 $\pm 0.35 \mathrm{mg} \mathrm{GAE} / \mathrm{g}$ sample. The high content of this compound in Sargassum sp. ethyl acetate extract is thought to have a soluble polyphenols biocompounds such as tannins and flavanols.

Solvent 


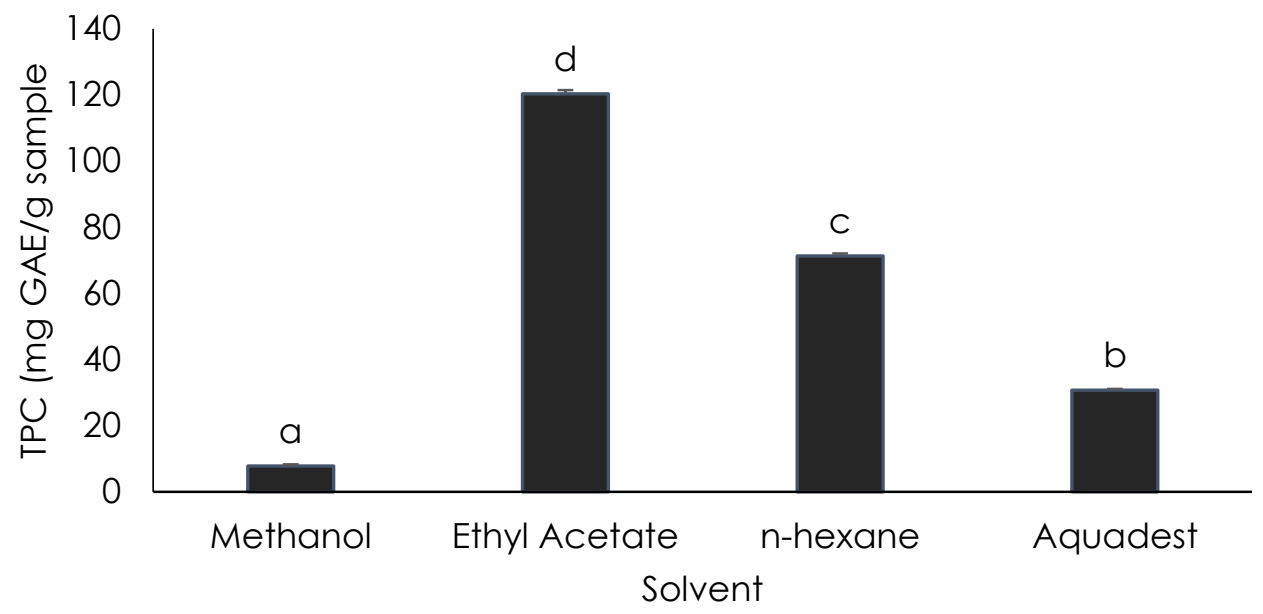

Figure 2. TPC value of Sargassum sp. Extract (ppm) macerated in different solvents. Bars with different letters indicate the significantly difference $(p<0.05)$.

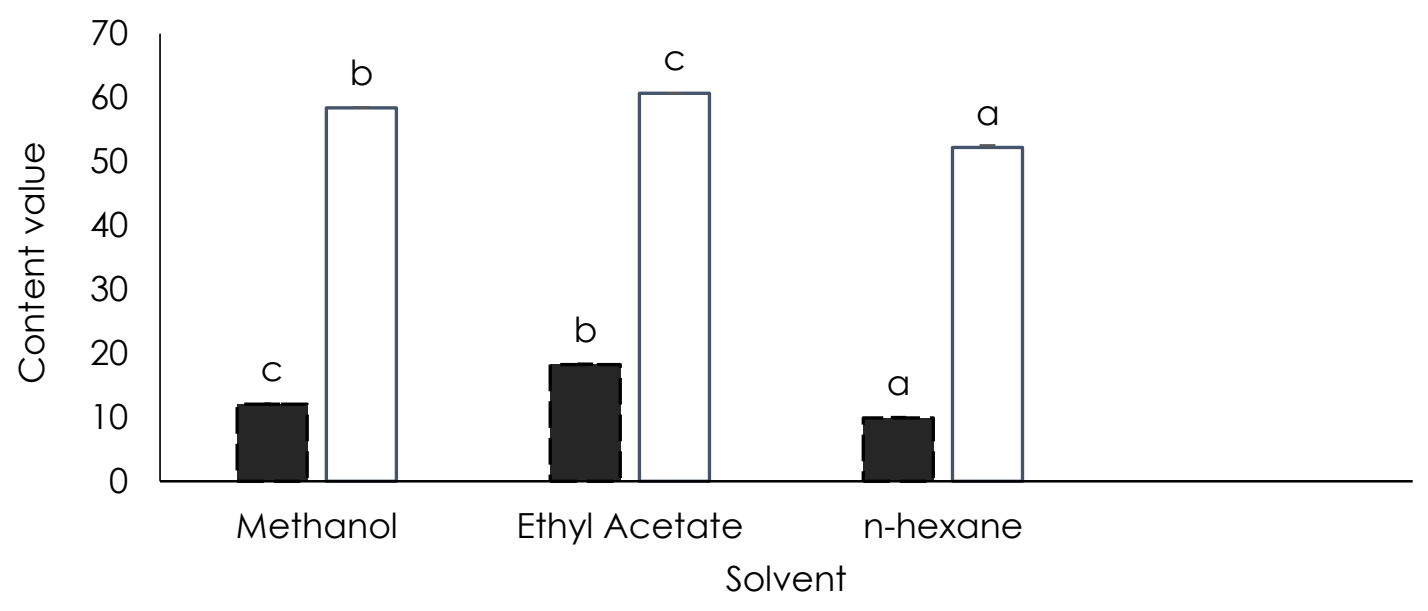

- Chlorophyll a (mg/g) $\quad$ Carotenoid $(\mu \mathrm{mol} / \mathrm{g})$

Figure 3. Pigment content of Sargassum sp. macerated in different solvents. Bars with different letters indicate the significantly difference $(p<0.05)$.

Antioxidant activity can also be affected by pigment content. Chlorophyll a and carotenoids are extracted using organic solvents such as methanol, ethyl acetate and $\mathrm{n}$-hexane. It is because carotenoids are hydrophobic (Saini and Keum, 2018). Hydrophobic is a property of a substance that repels water, lacking affinity for water, and tend to repel or not to absorb water. Results of Sargassum sp. extract pigment (Figure 3.) shows that the highest chlorophyll a and carotenoid was reached by ethyl acetate extract $18.23 \pm 0,049 \mathrm{mg} / \mathrm{g}$ and $60.65 \pm 0,008$ $\mu \mathrm{mol} / \mathrm{g})$.
Chlorophyll is the main pigment found in seaweed and has the potential effect to reduce the free radicals from DPPH (Sayuti and Yenrina, 2015). Another pigment that have the same functions is carotenoids. This pigment acts to help chlorophyll to absorb energy from light. One of the pigments from the carotenoid group produced by brown seaweed is fucoxanthin. This pigment has the potential to be developed as cosmeceutical and nutraceuticals materials especially as an antioxidant agent (Mise et al., 2011) and also suitabe to be applied into food products (Yip et al., 2014) 


\section{CONCLUSION}

Sargassum sp. Extract macerated in aquadest solvent has the strongest antioxidant activity with $\mathrm{IC}_{50}$ value $(72.95$ $\pm 0.22 \mathrm{ppm}$ ). Total phenolic compound (120.29 $\pm 0.404 \mathrm{mg}$ GAE/ g sample), chlorophyll a content (18.23 $\pm 0.049 \mathrm{mg} / \mathrm{g})$ and carotenoid content $(60.65 \pm 0.008 \mathrm{\mu mol} / \mathrm{g})$. Extraction using aquadest solvent, combined with stirring and heating can increase the antioxidant activity of the sample.

\section{REFERENCES}

Agustini, T.W., Suzeryb, M., Sutrisnanto, D., Ma'rufa, W.F. \& Hadiyanto. 2015. Comparative Study of Bioactive Substances Extracted from Fresh and Dried Spirulina sp. Proc. Environ. Sci. 23:282-289.

Banerjee, A., Dasgupta, N. \& De. B. 2005. In Vitro Study of Antioxidant Activity of Syzygium cumini fruit. J. Food Chem., 10(4):727-733.

Budhiyanti, S.A., Raharjo, S., Marseno, D.W. \& lelana, I.Y.B. 2012. Antioxidant Activity of Brown Algae Sargassum Species Extract from the Coastline of Java Island. Am. J. Agricul. Biolog. Sci. 3(7):337-346.

Cho, S.H. 2007. The Antioxidant Properties of Brown Seaweed (Sargassum siliquastrum). J. Med. Food, 10(3):479-485.

Diachanty, S., Nurjanah \& Abdullah, A. 2017. Aktivitas antioksidan berbagai jenis rumput laut coklat dari Perairan Kepulauan Seribu. J. Pengolahan Hasil Perikanan Ind. 20(2):305-318.

Fabrowska, J., Messyasz, B., Szyling, S., Walkowiak, J. \& Łęskal, B. 2017. Isolation of chlorophylls and carotenoids from freshwateralgae using different extraction methods. Phycol. Res. 66(1):5257.

Fitri, N. 2013. Butylated hydroxyanisole sebagai Bahan Aditif Antioksidan pada Makanan dilihat dari Perspektif Kesehatan. J. Kefarmasian Ind. 1 (4):41-50.

Frary, A. \& Earle, E.D. 1996. An examination of factors affecting the efficiency of Agrobacterium- mediated transformation of tomato. Plant cell reports, 16:225-240.

Gazali, M., Nurjanah \& Zamani, N.P, 2018, Eksplorasi senyawa bioaktif alga cokelat
Sargassum sp. Agardh sebagai Antioksidan dari pesisir barat Aceh. J. Pengolahan Hasil Perikanan Ind. 21(1):167-178

Ghafar, M.F.A., Prasad, K.N., Weng, K.K., \& Ismail, A. 2010. Flavonoid, Hesperidine, Total Phenolic Contents and Antioxidant Activities from Citrus Species. African J. Biotechnol. 9(3):326-330.

Gross, J, 1991, Pigments In Vegetables. Chlorophylls and Carotenoids, An avi Book Van Nostrand Reinhold, New York.

Harborne, J.B. 1987, Phytochemical Methods (Metode Fitokimia), Ed.1, diterjemahkan oleh Padmawinata K, Soediro I,Institut Teknologi Bandung, Bandung.

Harborne, J.B. 1996, Phytochemical Methods (Metode Fitokimia), Ed.2, diterjemahkan oleh Padmawinata K, Soediro I,Institut Teknologi Bandung, Bandung.

Hidayati, F., Darmanto, Y.S. \& Romadhon. 2017. Pengaruh Perbedaan Konsentrasi Ekstrak Sargassum sp. dan Lama Penyimpanan terhadap Oksidasi Lemak pada Fillet Ikan Patin (Pangasius sp.). J. Ilmu Lingk. 15(1):64-73.

Hidayati, J.R., Ridlo, A. \& R. Pramesti. 2017. Aktivitas Antioksidan Ekstrak Rumput Laut Padina sp. Dari Perairan Bandengan Jepara dengan Metode Transfer Elektron. Buletin Oseanografi Marina, 6(1):46-52.

Hwang, P., Wu, C., Gau, S., Chien, S.Y. \& Hwang, D. 2010. Antioxidant and Immune-Stimulating Activities of $\mathrm{Hot}$ Water Extract from Seaweed Sargassum hemiphyllum. J. Mar. Sci. Technol., 18(1):41-46.

Iltera, I., Akyıla, S., Demirelc, Z., Koçb, M., Conk-Dalayc M. \& Kaymak-Ertekina. 2018. Optimization of phycocyanin extraction from Spirulina platensis using different techniques. J. Food Composit. Anal., 70:78-88.

Khairy, H.M. \& El-Sheikh, M.A. 2015. Antioxidant Activity and mineral composition of Three Mediterranean common seaweeds from Abu-Qir Bay, Egypt. Saudi J. Biolog. Sci. 22:623-630.

Khaled, N., Hiba, M., Asma, C. 2012. Antioxidant and Antifungal activities of Padina Pavonica and Sargassum vulgare from the Lebanese Mediterranean Coast. Adv. Environment. Biolog. 6(1): 42-48. 
Kurniawan, M. 2010. Kandungan Klorofil, Karotenoid dan Vitamin C pada Beberapa Spesies Tumbuhan Akuatik. Anatomi Fisiologi. 18(1):28-40.

Mardiyah, U., Fasya, A.G., Fauziyah, B. \& Amalia, S. 2014. Ekstraksi, Uji Aktivitas Antioksidan dan Identifikasi Golongan Senyawa Aktif Alga Merah Eucheuma spinosum dari Perairan Banyuwangi. J. Alchemy, 3(1):39-46.

Mehdinezhad, N., Ghannadi, A. \& Yegdaneh, A. 2016. Phytochemical and Biological evaluation of some Sargassum species from Persian Gulf. Res. Pharmaceut. Sci. 11 (3):243-249.

Mirghani, M.E.S., Elnour, A.A.M., Kabbashi, N.A., Alam, M.Z., Musa, K.H. \& Abdullah, A. 2018. Determination of antioxidant activity of gum Arabic: An exudation from two different locations. Sci. Asia, 44:177-186.

Mise, T., Ueda, M. \& Yasumoto, T. 2011. Production of fucoxanthin-rich powder from Cladosiphon okamuranus. Adv. J. Food Sci. Technol. 3(1):73-76

Molyneux, P. 2004. The Use of The Stable Free Radical Diphenylpicrylhydrazyl (DPPH) for Estimating Antioxidant Activity. J. Sci. Technol. 26(2):212-219.

Moubayed, N.M.S., Al Houri, H.J., Al Khulaifi, M.M. \& Al Farraj, D.A. 2017. Antimicrobial, Antioxidant Properties and Chemical Composition of Seaweed Collected from Saudi Arabia (Red Sea and arabian Gulf). Saudi J. Biolog. Sci. 24(1):162-169

Nagappan, H., Pee, PP., Kee, SHY., OW, JT., Yan, SW., Chew, LY. \& Kong, KW. 2017. Malaysian brown seaweeds Sargassum siliquosum and Sargassum polycystum: low density lipoprotein (LDL) oxidation, angiotensinconverting enzyme (ACE),aamylase and a-glucosidase inhibition activities. Food Res. Int. 16(2):211-219.

Nicklisch, S.C.T \& Waite, J.H. 2014. Optimized DPPH assay in a detergent-based buffer system for measuring antioxidant activity of proteins. MethodsX, 1:233-238.

Nimse, S.B. \& Pal, D. 2015. Free radicals, natural antioxidants, and their reaction mechanisms. J. Royal Soc. Chem. 5:27986-28006.

Norra, I., Aminah, A. \& Suri, R. 2016. Effect of drying methods, solvent extraction and particle size of Malaysian brown seaweed, Sargassum sp. on the total phenolic and free radical scavenging activity. Int. Food Res. J. 23(4):1558-1563.

Nurjanah, Nurilmala,M., Hidayat, T. \& Sudirjo, F. 2016. Characteristics of Seaweed as Raw Materials for Cosmetics. Aquatic Procedia, 7:177-180.

Nursid, M., Wikanta, T. \& Susilowati, R. 2013. Aktivitas Antioksidan, Sitotoksisitas dan Kandungan Fukosantin Ekstrak Rumput Laut Coklat dari Pantai Binuangeun, Banten. J. Ilmu Kelautan, 8(1):73-84.

Padua, D., Rocha, E., Garguilo, D. \& Ramos, A.A. 2015. Bioactive Compounds from Brown Seaweeds: Phloroglucinol, Fucoxanthin and Fucoidan as Promising Therapeutic Agents Against Breast Cancer. Phytochemistry Letters., 14:91-98.

Parthiban, C., Saranya, C., Somasundaram, T. \& Anantharaman, P. 2014. Antioxidant Activities of Some Selected Seaweeds from Tuticorin Coast, Tamilnadu, India. Int. J. Phytopharm. Res. 5(1):36-41.

Puspita, M., Deniel, M., Widowati, W., Radjasa, O.K., Douzenel, P., Bedoux, G. \& Bourgougnon, N. 2017. Antioxidant and antibacterial activity of solid-liquid and enxyme-assisted extraction of phenolic compound from three species of tropical Sargassum. IOP Conf. Ser.: Earth Environ. Sci. 55:012057.

Sadati, N., Khanavi, M., Mahrokh, A., Nabavi, S.M.B, Sohrabipour, J. \& Hadjiakhoondi. 2015. Comparison of Antioxidant Activity and Total Phenolic Contents of Some Persian Gulf Marine Algae. J. Med. Plants. 10(37):73-79.

Saini, R.K. \& Keum, Y,S. 2018. Carotenoid extraction methods: A review of recent developments. J. Food Chem.240:90-103.

Sarastani, D., Soekarto, S.T., Muchtadi, T.R., Fardiaz, D. \& Apriyantono, A. 2002. Aktivitas Antioksidan Ekstrak dan Fraksi Ekstrak Biji Antung (Parinarium glaberrimum). J. Teknol. Ind. Pangan. 13(2):149-156.

Sarini, AW., Aishah, H.N. \& Zaini, N.M. 2014. Determination of antioxidant activity For seven types of macroalgae. Int. Conf. Food Eng. Biotechnol., 65:51-56.

Sathya, R., Kanaga, N., Sankar, P. \& Jeeva, S. 2017. Antioxidant Properties of 
Phlorotanninsfrom Brown Seaweed Cystoseira trinodis (Forsskal) C. Agardh. Arabian J. Chem. 10:2608-2614.

Sayuti, K. and Yenrina, R., 2015, Antioksidan Alami dan Sintetik. Andalas University Press, Padang.

Sedjati, S., Supriyantini, E., Ridlo, A., Soenardjo, N. \& Santi, V.Y. 2018. Kandungan Pigmen, Total Fenolik dan Aktivitas Antioksidan Sargassum sp. J. Kelautan Tropis, $21(2): 137-144$.

Sedjati, S., Suryono, Santosa, A., Supriyantini, E. \& Ridlo, A. 2017. Aktivitas Antioksidan dan Kandungan Senyawa Fenolik Makroalga Coklat Sargassum sp. J. Kelautan Tropis, 20(2):117-123.

Senapati, S.R., Sing, C.B., Hassan, M.A., Vignaesh, D. Xavier, K.A.M. \& Balange, A.K. 2016. Effect of Different Solvent on Total Phenolics and Antioxidant Activity of extract from Sargassum tenerrimum. J. Env. Bio-Sci, 30(2):415-419.

Shipeng, Y., Woo, H., Choi, J., Park, Y. \& Chun, B. 2015. Measurement of Antioxidant Activities and Phenolic and Flavonoid contents of the Brown Seaweed Sargassum horneri: comparison of Supercritical $\mathrm{CO} 2$ and Various Solvent Extraction. Fish Aquat. Sci., 18(2):123-130.

Tanniou, A., Vandanjon, L., Incera, M., Leon, E.S., Husa, V., Grand, J., Nicolas, J.,
Poupart, N., Kervarec, N., Engelen, A., Waish, R., Guerard, F., Bourgougnon, N. \& Stiger-pouvreau, V. 2014. Assessment of the spatial variability of phenolic contents and associated bioactivities in the invasive alga Sargassum muticulum sampled along its European range from Norway to Portugal. J. Appl. Phycol, 26:1215-1230.

Yip, W.H., Joe, L.S., Mustapha WAW., Maskat, MY. \& Said, M. 2014. Characterisation and Stability of Pigments Extracted from Sargassum binderi Obtained from Semporna, Sabah. Sains Malaysiana, 43(9):1345-1354.

Yudiati, E., Pringgenies, D., Djunaedi, A., Arifin, Z. \& Sudaryono, A. 2018a. Free Radical Scavenging of Low Molecular Weight Sodium Alginate (LMWSA) from Sargassum polycystum Produced by Thermal Treatment. Aquacul. Ind. 19(1): 21-27.

Yudiati, E., Santosa, G.W., Tontowi, M.R., Sedjati, S., Supriyantini, E. \& Khakimah, M. $2018^{b}$. Optimization of alginate alkaline extraction technology from Sargassum polycystum and its antioxidant properties. IOP Conf. Ser.: Earth Environ. Sci. 139:012052. 